\title{
Synergistic effects of steroids with FSH on folliculogenesis, steroidogenesis and FSH- and hCG-receptors in hypophysectomized mice
}

\author{
X. N. Wang and G. S. Greenwald* \\ Department of Physiology, Ralph L. Smith Research Center, University of Kansas Medical Center, \\ Kansas City, KS 66160, USA
}

\begin{abstract}
Injection of ovine FSH $\left(4 \mu \mathrm{g}_{\text {day }}{ }^{-1}\right)$ for 4 days into hypophysectomized mice does not restore folliculogenesis to normal cyclic values. This may be due to insufficient production of oestradiol. The present study was designed to determine whether FSH- and LH-induced oestradiol was critical for growth and differentiation of follicles at all stages. Twelve days after hypophysectomy, mice were injected s.c. with 10,50 or $250 \mu \mathrm{g}$ oestradiol cyclopentylpropionate daily with or without ovine FSH $\left(4 \mu \mathrm{g} \mathrm{day}^{-1}\right)$ for $1-4$ days. One ovary from each animal was used for histology. From the second ovary, follicles were isolated at different stages and incubated with $\left[{ }^{3} \mathrm{H}\right]$ thymidine for $3 \mathrm{~h}$ to determine the rate of DNA synthesis. Incubation medium and serum were used for steroid determinations. After oestradiol treatment alone, there was a dose-dependent response in serum oestradiol, but ovarian and uterine weights did not increase further with the increasing doses of oestradiol administered. This finding was consistent with an increase in the number of preantral follicles and small antral follicles but excluding the development of preovulatory follicles. Treatment with 10 and $50 \mu \mathrm{g}$ of oestradiol cyclopentylpropionate did not prevent antral follicles from undergoing atresia. The higher dose $\left(250 \mu \mathrm{g} \mathrm{day}^{-1}\right)$ of oestradiol cyclopentylpropionate delayed atresia of antral follicles and maintained more large healthy antral follicles. After concurrent injection of oestradiol and FSH, ovarian weight was 2-3 times greater than with either FSH or oestradiol alone; the number of follicles and follicular DNA synthesis at all stages of development increased without any signs of atresia; the in vitro accumulation of oestradiol also increased. Oestradiol alone induced FSH receptors in granulosa cells, but did not induce hCG receptors in any ovarian compartment; FSH alone induced FSH and hCG receptors in granulosa cells but not in thecal-interstitial tissues, whereas, oestradiol plus FSH enhanced FSH receptors in granulosa cells and LH/hCG receptors in granulosa and thecalinterstitial tissues. The synergistic effect of oestradiol with FSH was mimicked by the same dose of diethylstilboestrol, testosterone or dihydrotestosterone, but the latter steroids increased only the number of antral follicles, presumably because of their shorter half-lifes. These results indicate that in mice oestradiol stimulates the growth of preantral and antral follicles and delays follicular atresia; oestrogens and androgens act synergistically with FSH to enhance follicular proliferation and differentiation, and prevent follicles from undergoing atresia.
\end{abstract}

\section{Introduction}

Pituitary gonadotrophins play a pivotal role in ovarian follicular development and steroidogenesis. Previous studies have demonstrated that hypophysectomy of adult mice decreases the number of follicles at all stages of development and the rate of follicular DNA synthesis (Wang and Greenwald, 1993a). Replacement of FSH in hypophysectomized mice stimulates the growth of preantral follicles to preovulatory stages and induces FSH and LH receptors only on granulosa cells. However, FSH alone does not induce $\mathrm{LH}$ receptors on thecal and interstitial

*Reprint requests.

Received 9 November 1992. tissue, nor will it stimulate oestradiol production or prevent antral follicles from undergoing atresia (Wang and Greenwald, 1993b). Combined treatment with FSH and LH restores follicular structure and function to normal pro-oestrous values, in terms of the number of growing follicles at all stages of development, the rate of proliferation of granulosa cells, the distribution of FSH and LH receptors and oestradiol production (Wang and Greenwald, 1993b). This suggests that FSH and LH are both required for folliculogenesis, encompassing initiation, proliferation, differentiation and culminating in ovulation.

It is not known how LH acts on preantral follicles to synergize with the effects of FSH as there are no detectable LH receptors in granulosa cells of the early developmental follicles. On the basis of previous studies in rats, it is generally believed that oestrogens Downloaded from Bioscientifica.com at 04/26/2023 12:48:33PM 
are essential for normal follicular development (Richards, 1980; Hsueh, 1986). In hypophysectomized immature rats, oestrogens enhance the proliferation of granulosa cells, diminish follicular atresia, augment the activities of steroidogenic enzymes, including aromatase activity, and induce their own receptors in granulosa cells and FSH and LH receptors (Goldenberg et al., 1972; Kessel et al., 1985; Hutz, 1989; Tonetta and diZerega, 1989). These results strongly indicate folliculotrophic effects of oestrogens on granulosa cells and growth of preantral and antral follicles. On the basis of these studies in rats, one hypothesis for the effect of $\mathrm{LH}$ on preantral follicles in hypophysectomized mice is that LH synergizes with FSH to stimulate oestrogen production; the latter, in turn, induces proliferation of granulosa cells and steroidogenesis, and subsequently increases the sensitivity of the follicle to further gonadotrophin stimulation.

The effects of steroids on follicular development and steroidogenesis in mice are unclear. There are only a few reports about the effects of oestrogen in immature mice, and it apparently exerts stimulatory or inhibitory effects on follicular development (Kent, 1973; Kim and Greenwald, 1987; Halling and Forsberg, 1990). The present study, using hypophysectomized cyclic mice as the experimental model, was undertaken to determine whether exogenous oestrogens and androgens are directly involved in (1) the preantral and early antral follicular development, by determining mean number and status of follicles as well as rate of DNA synthesis of isolated follicles at different developmental stages and (2) follicular differentiation, by measuring steroid concentrations in serum and the medium from incubated preovulatory follicles and localizing ovarian FSH- and LH/hCG-receptors.

A preliminary report of these results was presented at the 25th Annual Meeting of Society for the Study of Reproduction, North Carolina State University, Raleigh, July 1992.

\section{Materials and Methods}

\section{Hypophysectomy and treatment}

Adult female ICR mice (7-8 weeks old) were obtained from Harlan Co. (Madison, WI), and maintained under standard lighting conditions of $14 \mathrm{~h}$ light:10 h dark (lights on 06:00 h) at $20^{\circ} \mathrm{C}$. Cyclic animals at random stages of the oestrous cycle were hypophysectomized by a parapharyngeal approach under Avertin (tribromoethyl alcohol, $0.4 \mathrm{ml}$ of $2.5 \%$ ) anaesthesia (day of hypophysectomy $=$ day 0 ). After hypophysectomy, the drinking water was supplemented with $5 \%$ glucose. Completeness of hypophysectomy was assessed by previously described criteria (Smith and Tenney, 1979), and incompletely hypophysectomized animals were not included in the study. On day 12 , animals were injected s.c. for $1-4$ days with either (1) $20 \%$ polyvinyl pyrrolidone in saline or peanut oil (vehicle for steroids; hypophysectomized control group); or (2) NIDDK-oFSH-17 $\left(4 \mu \mathrm{g} \mathrm{day}^{-1}\right)$ in polyvinyl pyrrolidone twice a day (a gift from the National Hormone and Pituitary Program, Baltimore, MD); or (3) different daily doses $\left(10,50\right.$ or $250 \mu \mathrm{g}$ day $\left.^{-1}\right)$ of oestradiol cyclopentylpropionate (Upjohn, Kalamazoo, MI), an esterified oestrogen; or (4) oFSH-17 $\left(4 \mu \mathrm{g}\right.$ day $\left.^{-1}\right)$ plus $250 \mu \mathrm{g}$ day $^{-1}$ of oestradiol cyclopentylpropionate, diethylstilboestrol, dihydrotestosterone or testosterone; the last three were purchased from Sigma (St Louis, MO). At 09:00 h after 1-4 days of treatment, animals were decapitated under ether anaesthesia and serum was saved for steroid assays. Ovaries and uteri were collected and weighed after drying on paper tissues.

\section{Preparation for light and electron microscopy}

One ovary from each animal was fixed in Bouin's fluid, overnight and sectioned serially at $7 \mu \mathrm{m}$. After routine histological processing, the sections were stained with haematoxylin-eosin. Follicles in the section in which the ovum and nucleolus were present were counted and classified as healthy or atretic. The presence of at least three pyknotic nuclei for stage 1-3 follicles and five pyknotic nuclei for stages $4-6$ (defined below) in the largest cross-section of the follicle in which the nucleolus of the oocyte was present was considered as signs of early atresia; follicles with more than ten pyknotic nuclei were defined as late atretic follicles.

For preparation of specimens for electron microscopy, sliced ovarian tissues were fixed in $3 \%$ glutaraldehyde and post-fixed in $1 \%$ osmium tetroxide. The dehydrated tissues were then infiltrated and embedded in a 1:1 mixture of propylene oxide and epoxy resin. The trimmed tissues were sectioned using an LKB Nova ultramicrotome and the thin sections were stained by uranyl acetate and lead citrate solution. The stained sections were viewed and photographed with a JEOL JEM-100S transmission electron microscope.

\section{Isolation of follicles and incubation of follicles with $\left.{ }^{3} \mathrm{H}\right]$ thymidine}

The contralateral ovary to the one used for histology was cleaned; antral follicles (stages 4-6) were dissected out with watch-maker forceps; and preantral follicles (stages 1-3) were digested from the remaining ovarian tissue with a mixture of collagenase (Type 5) and DNase I in Kreb's-Ringer buffer containing $25 \mathrm{mmol}$ Hepes $\mathrm{l}^{-1}$ (Wang et al., 1991). The isolated follicles (four replicates per stage) were incubated in 24-well culture clusters containing $700 \mu \mathrm{l}$ buffer with $0.5 \% \mathrm{BSA}$ for $3 \mathrm{~h}$ at $37^{\circ} \mathrm{C}$ in the presence of $0.5 \mu \mathrm{Ci}\left[{ }^{3} \mathrm{H}\right]$ thymidine (Wang et al., 1991). The number of follicles incubated for each stage was as follows: $50-70$ stage 1 follicles (with a single layer of granulosa cells); $20-25$ stage 2 follicles (two layers of granulosa cells); 20 stage 3 follicles (three or more layers of granulosa cells); 6 stage 4 follicles (incipient antrum); 5 stage 5 follicles (intermediate antrum) and 4 stage 6 (preovulatory follicles). The incubation was terminated by transferring follicles into $200 \mu \mathrm{l}$ ice-cold DNA-assay buffer containing $50 \mu \mathrm{g}$ unlabelled thymidine (Roy and Greenwald, 1986), and the follicles and the spent incubation medium were stored at $-20^{\circ} \mathrm{C}$ until assayed for DNA content, radioactivity and steroids.

Follicular DNA content and incorporation of radionuclide into DNA were measured by fluorometry and scintillation counting, respectively (Roy and Greenwald, 1986). The results of incorporation of $\left[{ }^{3} \mathrm{H}\right]$ thymidine into follicles were expressed as fmol $\left[{ }^{3} \mathrm{H}\right]$ thymidine $\mu \mathrm{g}^{-1}$ follicular DNA in $3 \mathrm{~h}$.

\section{Assay of steroids in serum and in incubation medium}

Progesterone, androstenedione and oestradiol were assayed by radioimmunoassay as described by Terranova and Greenwald Downloaded from Bioscientifica.com at 04/26/2023 12:48:33PM 
(1978) and Wang and Greenwald (1993b). Non-specific binding and recoveries were performed for each assay. The lower limits of sensitivity in the assays for progesterone, androstenedione and oestradiol were 5,2 and 2 pg per assay tube, respectively.

The spent medium $(700 \mu \mathrm{l}$ per well) from incubation of isolated follicles with $\left[{ }^{3} \mathrm{H}\right]$ thymidine was used for steroid measurements. A preliminary experiment showed that after ether extraction and charcoal isolation of free and bound $\left[{ }^{3} \mathrm{H}\right]$-labelled hormones, free $\left[{ }^{3} \mathrm{H}\right]$ thymidine in the incubation medium was removed completely and was within the background range of the radioimmunoassay. The incubation medium initially containing $\left[{ }^{3} \mathrm{H}\right]$ thymidine was therefore used for steroid radioimmunoassays. Samples of $200 \mu \mathrm{l}$ incubation medium were used to measure progesterone, androstenedione and oestradiol. About $400 \mu \mathrm{l}$ serum was obtained from each mouse with $200 \mu \mathrm{l}$ of serum used for the assay of oestradiol, about $100 \mu \mathrm{l}$ for progesterone and $100 \mu \mathrm{l}$ for androstenedione. All the incubation and serum samples were extracted with $2 \mathrm{ml}$ of diethyl ether. Samples from each group were assayed at one time to avoid interassay variation. The results of in vitro steroid accumulations were expressed as pg per follicle in $3 \mathrm{~h}$ and serum steroids were expressed as $\mathrm{pg} \mathrm{ml}^{-1}$ serum.

\section{Autoradiography for FSH and hCG receptors}

Cleaned ovaries were frozen in liquid freon and stored at $-80^{\circ} \mathrm{C}$. A week before autoradiography, ovaries were sectioned at $8 \mu \mathrm{m}$ in a cryostat at $-20^{\circ} \mathrm{C}$. The procedures for iodination, characterization and other preparation for autoradiography are described by Oxberry and Greenwald (1982) and Wang and Greenwald (1993a).

All hormones were supplied by the National Pituitary Hormone Program. Rat FSH I-8 (FSH bioactivity $=100 \times$ NIH FSH S-1 or $4714 \mathrm{iu} \mathrm{mg}^{-1}$ of the 2nd IRP-HMG) and hCG CR-127 (14 $900 \mathrm{iu} \mathrm{mg}^{-1}$ ) were labelled with $\mathrm{Na}{ }^{125}$ I(IMS.300; Amersham, Arlington Heights, IL) by the lactoperoxidase method (Catt et al., 1976) and characterized as described by Kim and Greenwald (1986) and Roy et al. (1987). The specific activities for the iodinated FSH and hCG were 27 and $31 \mu \mathrm{Ci}$ $\mu \mathrm{g}^{-1}$; and the active fractions were 32 and $60 \%$, respectively.

All labelled and unlabelled hormones were diluted with $0.05 \mathrm{~mol}$ Tris buffer $1^{-1}$ containing $0.01 \mathrm{~mol} \mathrm{CaCl} \mathrm{I}^{-1}$, $0.02 \mathrm{~mol} \mathrm{MgCl}_{2} \mathrm{I}^{-1}$ and $0.1 \% \mathrm{BSA}$. The sections were incubated at $37^{\circ} \mathrm{C}$ for $90 \mathrm{~min}$ with a $100 \mu \mathrm{l}$ drop of 20000 c.p.m. of ${ }^{125}$ I-labelled rat $\mathrm{rFSH}$ or hCG. Nonspecific binding was determined by incubating sections in the presence of a 500-fold excess of unlabelled homologous hormone in addition to labelled hormone. Specific binding was determined by incubating sections with ${ }^{125}$ I-labelled hormone plus a 500 -fold excess of one of the unlabelled heterologous hormones. After incubation, the sections were washed in three changes of phosphate buffered saline at $4^{\circ} \mathrm{C}$ and postfixed for $10 \mathrm{~min}$ in $3 \%$ glutaraldehydephosphate buffered saline. After rinsing and air-drying, the sections were coated with Kodak NTB-2 liquid emulsion, exposed at $4^{\circ} \mathrm{C}$ for two weeks for hCG binding or three weeks for FSH binding, developed in Dektol (Kodak) and stained with haematoxylin.
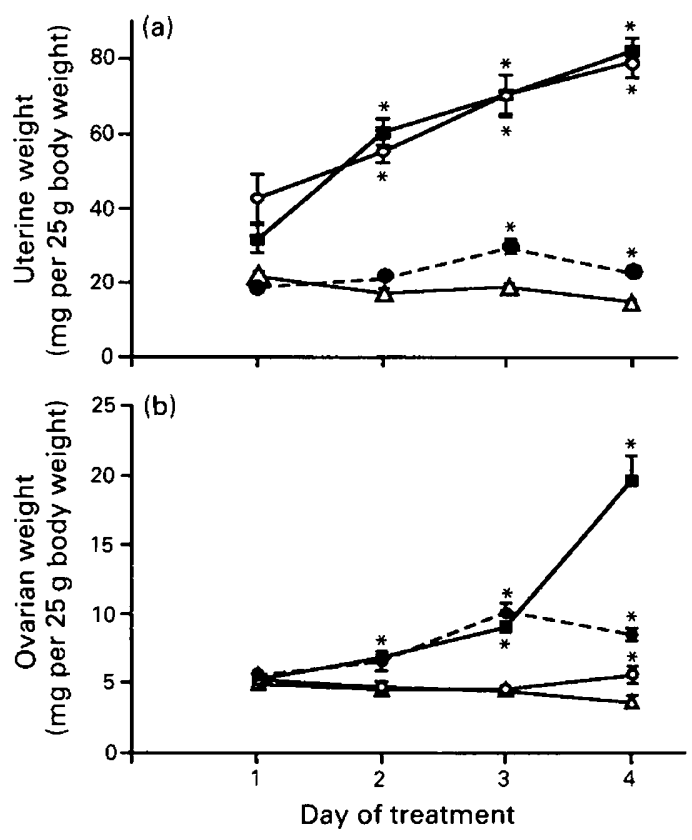

Fig. 1. Effects of replacement of FSH and oestradiol on uterine and ovarian weights in hypophysectomized mice. (a): uterine weight; (b): ovarian weight. (O) $250 \mu \mathrm{g}$ oestradiol day ${ }^{-1}$, (O) $4 \mu \mathrm{g} \mathrm{FSH} \mathrm{day}^{-1}$ or (ם) FSH plus oestradiol were injected beginning on day 12 after hypophysectomy for 4 days. The mean ( \pm SEM) were based on $25 \mathrm{~g}$ of body weight from four to six animals in each group. ${ }^{*}$ The weight of these groups were significantly increased $(P<0.05)$ compared with $(\triangle)$ hypophysectomized controls on the same day of treatment.

\section{Statistical analysis}

One-factor ANOVA followed by the Fisher protected least significant difference or Duncan's new multiple range test were used for most data analysis and two-factor ANOVA followed by the least squares means test of $\mathrm{T}$ was applied for multiple comparisons for the data in Fig. 1 by using the Super ANOVA program (Abacus Concepts, Inc. Berkeley, CA) on a Macintosh computer. Values were considered statistically different when significance was at least $P<0.05$.

\section{Results}

\section{Ovarian and uterine weight}

After 4 days of injections of different doses ( 10,50 or $250 \mu \mathrm{g}$ day $^{-1}$ ) of oestradiol cyclopentylpropionate, serum oestradiol increased with the increasing doses administered, from about $10 \mathrm{pg} \mathrm{ml}^{-1}$ in the hypophysectomized control to $7830 \mathrm{pg} \mathrm{ml}^{-1}$ for the oestradiol group with highest dose $(250 \mu \mathrm{g})$. Ovarian and uterine weights increased significantly even by day 3 of the $10 \mu \mathrm{g}$ oestradiol injections $(P<0.05)$, and saturation was reached with higher doses. However, neither ovarian nor uterine weights were restored to pro-oestrous values. When oestradiol $\left(250 \mu \mathrm{g}\right.$ day $\left.^{-1}\right)$ was combined with FSH $(4 \mu \mathrm{g}$ day $\left.^{-1}\right)$ and administered to hypophysectomized mice for $1-4$ days, the rate and the maximum increase in uterine weight was not different from those of mice receiving oestradiol alone, but was much higher than those of the FSH-alone group (Fig. Ia). 


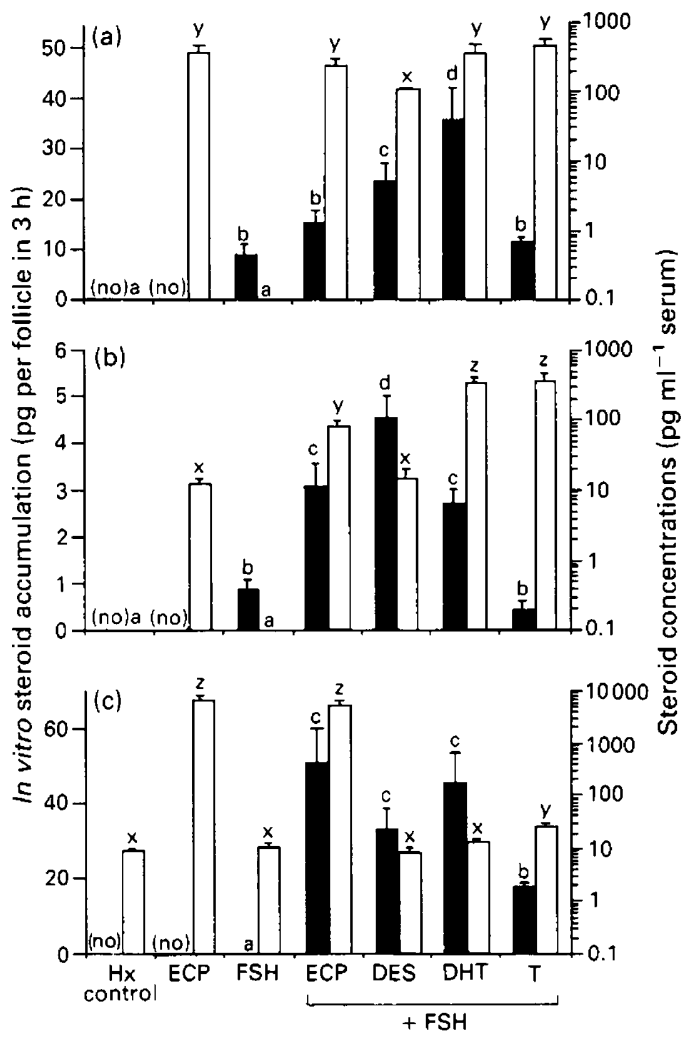

Fig. 2. Effects of replacement of FSH and/or oestradiol cyclopentylpropionate (ECP), diethylstilboestrol (DES), dihydrotestosterone $(\mathrm{DHT})$, testosterone $(\mathrm{T})$ on concentrations of (a) progesterone, (b) androstenedione and (c) oestradiol in serum $(\square)$ and in incubation medium ( $\square$ ) for isolated preovulatory (stage 6) follicles in HX mice. Note that there were no stage 6 follicles in hypophysectomized controls (HX) nor in the HX + ECP group (no); steroid concentrations were not detectable in the marked groups; ${ }^{b-d}$ values with different letters were significantly different $(P<0.05)$ among the groups for steroid accumulation in follicular incubation medium; ${ }^{x-z}$ values with different letters were significantly different $(P<0.05)$ among the groups for serum steroid concentrations.

However, ovarian weight in the oestradiol plus FSH group increased significantly $(P<0.05)$ compared with those of groups treated with FSH or oestradiol alone (Fig. 1b). Diethylstilboestrol, dihydrotestosterone or testosterone ( $250 \mu \mathrm{g}$ daily) also acted synergistically with FSH to increase ovarian and uterine weight (data not shown).

\section{Steroid concentrations after treatment for 4 days}

No preovulatory follicles (stage 6) were present in hypophysectomized controls or in the group receiving oestradiol alone; there was no detectable accumulation of steroids in the incubation medium for follicles smaller than stage 5 (Fig. 2). Serum progesterone and androstenedione were not detectable in hypophysectomized controls and the concentration of serum oestradiol was low (about $10 \mathrm{pg} \mathrm{ml}^{-1}$ ) in hypophysectomized controls and in groups receiving FSH alone, diethylstilboestrol plus FSH or dihydrotestosterone plus FSH. This might be the result of oestradiol-antibody crossreacting with oestrogen analogues, such as equol (Barkley et al., 1985). However, exogenous oestradiol $\left(250 \mu \mathrm{g}^{\text {day }^{-1}}\right)$ not only led to high concentrations of serum oestradiol, but also caused high concentrations of serum progesterone and androstenedione. As reported previously (Wang and Greenwald, 1993b), treatment of hypophysectomized mice with FSH alone did not increase serum concentrations of progesterone, androstenedione and oestradiol. In contrast to groups receiving oestradiol or FSH alone, the groups receiving FSH with oestradiol, diethylstilboestrol, dihydrotestosterone or testosterone secreted progesterone, androstenedione and oestradiol into serum and into the incubation medium at different rates (Fig. 2).

\section{Follicular development}

Treatment with oestradiol alone at lower doses (10 or $50 \mu \mathrm{g}$ day ${ }^{-1}$ ) for 4 days in hypophysectomized mice increased the number of healthy follicles at all stages of development (stages 1-5) compared with the hypophysectomized control group, but did not prevent follicles from becoming atretic, nor support follicles growing to the preovulatory stage (stage 6) (Table 1). A higher dose of oestradiol $\left(250 \mu \mathrm{g}\right.$ day $\left.^{-1}\right)$ significantly increased the number of stage $1-5$ follicles after 2 days of treatment (data not shown), but did not increase the number of preantral follicles (stages 1-3) significantly after 4 days of treatment, although the number of healthy medium-sized follicles (stages 4-5) was greater than in hypophysectomized controls. In the hypophysectomized group receiving $250 \mu \mathrm{g}$ oestradiol, about $60-70 \%$ atretic follicles were at an early atretic stage in which degenerating granulosa cells showed nuclear compaction in uniformly dense masses but not breakdown, fewer mitochondria, swollen rough endoplasmic reticulum and cytoplasmic condensation (Fig. 3a). In the remaining healthy granulosa cells of the same follicle, there were some focal sites of degeneration. These early atretic signs persisted for the 4 days of treatment with $250 \mu \mathrm{g}$ oestradiol day ${ }^{-1}$. Treatment with 10 and $50 \mu \mathrm{g}$ oestradiol day ${ }^{-1}$ or with FSH alone did not prevent follicles from undergoing atresia; $90 \%$ of the atretic follicles were at late stages (Fig. 3b). There were many pyknotic cells evenly scattered throughout the mural granulosa cells. The degenerating cells contained a broken pyknotic nucleus, electron-dense lipid droplets and unclear cytoplasmic organelles. A very low ratio of cytoplasm to nucleus was observed even in the relatively healthy cells in the advanced atretic follicles (Fig. 3b).

The combined injection of oestradiol and FSH in hypophysectomized mice significantly increased the number of follicles at all stages of development (stages 1-6) and caused superfollicular growth without any signs of atresia (Table 1). Diethylstilboestrol acted synergistically with FSH on folliculogenesis in the same way as oestradiol but was less potent because it has a shorter half-life than does oestradiol. In addition, androgens (dihydrotestosterone and testosterone), when substituted for oestrogens, enhanced the number of middle and large-sized follicles without increasing the number of small follicles. In the hypophysectomized group receiving testosterone, fewer follicles underwent atresia. Again, the shorter half-lifes of the androgens compared with oestradiol probably accounts for their inability to stimulate smaller follicles. 
Table 1. Effects of FSH, steroid replacement or both treatments on numbers of healthy and atretic follicles per mouse ovary (mean \pm SEM) at different developmental stages on day 16 after hypophysectomy (HX)

\begin{tabular}{|c|c|c|c|c|c|c|c|c|}
\hline \multirow[b]{2}{*}{ Treatment $^{a}$} & \multicolumn{8}{|c|}{ Stage of follicles } \\
\hline & 1 & 2 & 3 & & 4 & & 5 & 6 \\
\hline $\begin{array}{l}\mathrm{HX} \text { control } \\
\mathrm{HX}+\mathrm{ECP}\end{array}$ & $83 \pm 18$ & $68 \pm 19$ & $39 \pm 4$ & $7 \pm$ & $1(2) \dagger$ & $4 \pm$ & $0.3(14)$ & None \\
\hline $10 \mu \mathrm{g} \mathrm{day}^{-1}$ & $176 \pm 27^{*}$ & $125 \pm 21^{*}$ & $61 \pm 5^{*}$ & $26 \pm$ & $7^{*}(20)$ & $9 \pm$ & $2^{*}(18)$ & None \\
\hline $50 \mu \mathrm{g}_{\text {day }}{ }^{-1}$ & $164 \pm 28^{*}$ & $121 \pm 18^{*}$ & $54 \pm 5^{*}$ & $27 \pm$ & $7^{*}(9)$ & $7 \pm$ & $2(17)$ & None \\
\hline $250 \mu \mathrm{g}$ day $^{-1}$ & $109 \pm 7$ & $88 \pm 12$ & $58 \pm 4^{*}$ & $29 \pm$ & $5^{*}(3)$ & $20 \pm$ & $2^{*}(13)$ & None \\
\hline $\mathrm{HX}+\mathrm{FSH}$ & $148 \pm 20^{*}$ & $130 \pm 17^{*}$ & $71 \pm 8^{*}$ & $17 \pm$ & $2^{*}(6)$ & $13 \pm$ & $2^{*}(13)$ & $6 \pm 2^{*}(10)$ \\
\hline $\mathrm{HX}+\mathrm{FSH}+\mathrm{ECP}$ & $180 \pm 12^{*}$ & $126 \pm 14^{*}$ & $91 \pm 6^{*}$ & $38 \pm 1$ & $11^{*}$ & $37 \pm$ & $3^{*}$ & $73 \pm 13^{*}$ \\
\hline $\mathrm{HX}+\mathrm{FSH}+\mathrm{DES}$ & $160 \pm 27^{*}$ & $76 \pm 10$ & $58 \pm 8$ & $18 \pm$ & $2^{*}$ & $12 \pm$ & $2^{*}$ & $33 \pm 7^{*}$ \\
\hline $\mathrm{HX}+\mathrm{FSH}+\mathrm{DHT}$ & $113 \pm 18$ & $72 \pm 10$ & $64 \pm 11^{*}$ & $27 \pm$ & $3^{*}$ & $27 \pm$ & $6^{*}$ & $49 \pm 9^{*}$ \\
\hline $\mathrm{HX}+\mathrm{FSH}+\mathrm{T}$ & $86 \pm 9$ & $64 \pm 6$ & $56 \pm 6^{*}$ & $26 \pm$ & $5^{*}(4)$ & $22 \pm$ & $3^{*} \quad(3)$ & $44 \pm 5^{*}(6)$ \\
\hline
\end{tabular}

's.c. Injection of FSH $\left(4 \mu \mathrm{g} \mathrm{day}^{-1}\right)$ in polyvinyl pyrrolidone twice a day and s.c. injection $\left(250 \mu \mathrm{g} \mathrm{day}^{-1}\right)$ of oestradiol cyclopentylpropionate (ECP), diethylstilboestrol (DES), dihydrotestosterone (DHT) or testosterone (T) in peanut oil once a day for 4 days beginning at day 12 after hypophysectomy.

+ Values in parentheses are the mean number of atretic follicles at that stage.

${ }^{*} p<0.05$, comparing different treatment groups with the hypophysectomized control group within that developmental stage $(n=4-8)$.

\section{Incorporation of $\left[^{3}\right.$ H]thymidine}

The in vitro incorporation of $\left[{ }^{3} \mathrm{H}\right]$ thymidine into DNA of isolated follicles at different stages was used to evaluate the rate of follicular DNA synthesis (Table 2). The DNA content of follicles from hypophysectomized mice at most stages was unchanged from the content in cyclic mice (data not shown, see Wang et al., 1991), indicating that the cell mass in each follicle was similar before and after hormonal treatment. However, for the hypophysectomized group receiving FSH plus oestradiol, preovulatory follicles were induced after only 1 day of treatment and the DNA content of preovulatory follicles (stage 6) increased from $150 \pm 14 \mathrm{ng}$ per follicle after 1 day of treatment to $462 \pm 24 \mathrm{ng}$ per follicle after 4 days. This finding indicated that the preovulatory follicles grew continuously and atresia had been eliminated. After 3-4 days of treatment, the preovulatory follicles were larger than those from normal pro-oestrous mice. The rate of DNA synthesis was therefore expressed as fmol $\left[{ }^{3} \mathrm{H}\right]$ thymidine incorporated $\mu \mathrm{g}^{-1}$ DNA rather than per follicle.

Concomitant with the increase in the number of follicles, there was increased $\left[{ }^{3} \mathrm{H}\right]$ thymidine incorporation into preantral (stages 1-3) and antral (stages 4-6) follicles in the groups receiving $\mathrm{FSH}$ plus oestrogen and $\mathrm{FSH}$ plus diethylstilboestrol (Table 2). In the groups receiving FSH plus dihydrotestosterone or FSH plus testosterone, $\left[{ }^{3} \mathrm{H}\right]$ thymidine incorporation increased only in antral follicles (stages $4-6$ ). For groups treated with 10 or $50 \mu \mathrm{g}$ oestradiol alone, although the number of follicles increased in most stages (Table 1), the rate of DNA synthesis increased only in follicles at stages 2 and 4; incorporation of $\left[{ }^{3} \mathrm{H}\right]$ thymidine into follicles at stages $2-4$ increased in the group treated with $250 \mu \mathrm{g}$ oestradiol. Regardless of the dose of oestradiol, there was no increased incorporation of $\left[{ }^{3} \mathrm{H}\right]$ thymidine for follicles at stage 5, which was the last stage of follicular development attained in the absence of gonadotrophins, and is associated with reduced DNA synthesis and follicular atresia. The best result in terms of DNA synthesis was achieved by treatment with FSH plus oestradiol, in which increased incorporation of $\left[{ }^{3} \mathrm{H}\right]$ thymidine occurred in all stages of follicular development.

\section{FSH- and hCG-receptors}

Oestradiol induced FSH receptors in the granulosa cells of follicles larger than stage 3 (Fig. $4 \mathrm{a}, \mathrm{b}$ ), as did FSH alone (Fig. $4 \mathrm{c}$ ); $\mathrm{FSH}$ plus oestradiol resulted in a greater density of grains in granulosa cells compared with either FSH or oestradiol alone (Fig. 4d). For hCG receptors, trace amounts of $\left[{ }^{125} \mathrm{I}\right]$-labelled hCG binding was limited to the interstitium after oestradiol treatment (Fig. 5a), similar to the hypophysectomized control (not shown). As reported by Wang and Greenwald (1993b), treatment with FSH alone induced hCG receptors in granulosa cells only in follicles at stages 5 and 6 without thecal and interstitial binding sites (Fig. 5b). However, combined treatment with oestradiol and FSH induced hCG receptors not only in granulosa cells but also in the theca and interstitium (Fig. 5c,d), comparable to that in pro-oestrous mice and hypophysectomized mice treated with FSH plus LH. It is noteworthy that treatment with oestradiol plus FSH induced hCG receptors in granulosa cells, even in follicles at stage 3-4; this was not observed in pro-oestrous mice (Wang and Greenwald, 1993a).

\section{Discussion}

Hypophysectomized mice were used in this study to evaluate the actions of certain steroids, either alone or in combination with FSH, on follicular development and differentiation. The results demonstrate that oestrogens alone directly stimulate growth of follicles, but do not enhance follicular differentiation; however, oestrogen plus FSH stimulates both follicular growth and differentiation. The mechanisms for the synergistic effects 

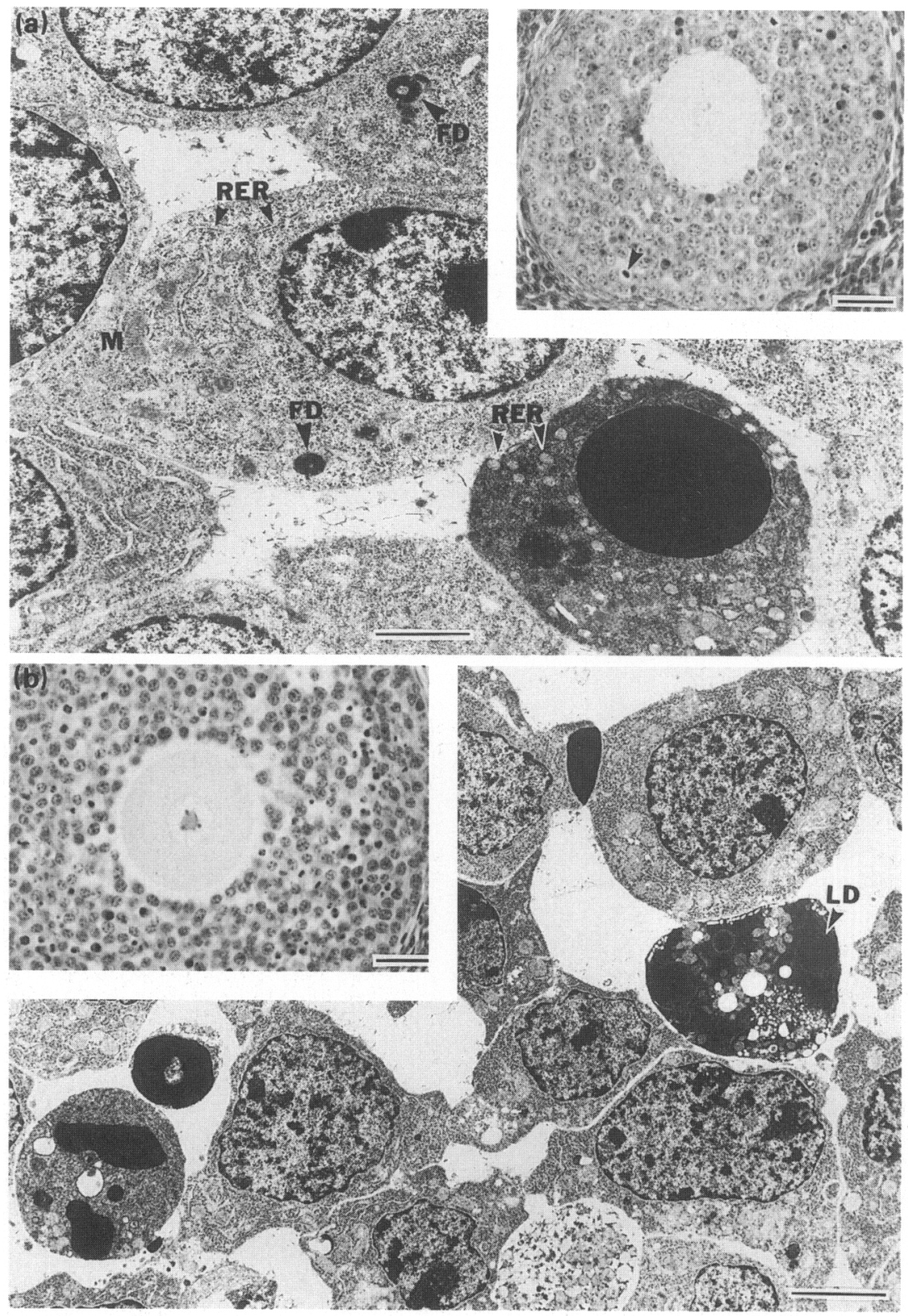

Fig. 3. Photomicrographs of follicles at stage 5 showing different degrees of atresia after (a) oestradiol or (b) FSH replacement in hypophysectomized mice. Oestradiol $\left(250 \mu \mathrm{g} \mathrm{day}^{-1}\right)$ or FSH ( $4 \mu \mathrm{g} \mathrm{day}^{-1}$ ) was injected for 4 days beginning on day 12 after hypophysectomy and the mice were killed on day 16. Insets of each panel are light micrographs. RER: rough endoplasmic reticulum; M: mitochondria; LD: lipid droplets; FD: focal sites of degeneration. Arrowheads point to mitoses. Note: there are also pyknotic nuclei (dark staining) scattered among healthy cells. Scale bars $=$ (a) $5 \mu \mathrm{m}$, (b) $10 \mu \mathrm{m}$, inserts: $20 \mu \mathrm{m}$.

of oestrogens with FSH involve enhancement of steroid production, especially oestradiol, and induction of ovarian FSH and LH/hCG receptors.

Williams (1940) and Pencharz (1940) were the first to demonstrate that diethylstilboestrol increased ovarian weight in hypophysectomized immature rats. The optimal stimulatory dose for this effect is 1-2 mg for 3-4 days (established by Payne and Hellbaum, 1955). On the basis of this and other studies (Goldenberg et al., 1972; Kim and Greenwald, 1987), the doses of oestrogen given to hypophysectomized mice were
$10-250 \mu \mathrm{g} \mathrm{day}^{-1}$ for $1-4$ days; these are lower than the optimal dose because of the relative longer half-life of oestradiol cyclopentylpropionate $(72 \mathrm{~h}$ in ovariectomized hamsters; Greenwald, 1975). After 4 days of treatment with oestradiol, serum oestradiol concentration was as high as $8000 \mathrm{pg} \mathrm{ml}^{-1}$ compared with $35 \mathrm{pg} \mathrm{ml}^{-1}$ in intact pro-oestrous mice (Wang and Greenwald, 1993b). A pharmacological dose of oestradiol was therefore used in an attempt to achieve significantly higher oestradiol concentrations in follicular fluid than in the serum (about 500-fold difference in rats; Goff and Henderson, 1979). 
Table 2. Effects of FSH and steroids on the incorporation of $\left[{ }^{3} \mathrm{H}\right]$ thymidine into follicular DNA of hypophysectomized mice $\left(\left[^{3} \mathrm{H}\right]\right.$ thymidine fmol $\mu \mathrm{g} \mathrm{DNA}^{-1}$, mean $\left.\pm \mathrm{SEM}\right)$

\begin{tabular}{|c|c|c|c|c|c|c|}
\hline \multirow[b]{2}{*}{ Treatment $^{a}$} & \multicolumn{6}{|c|}{ Stage of isolated follicles } \\
\hline & 1 & 2 & 3 & 4 & 5 & 6 \\
\hline $\mathrm{HX}$ control & $65.9 \pm 7.6$ & $111.0 \pm 15.4$ & $160.7 \pm 10.8$ & $117.8 \pm 9.6$ & $157.0 \pm 17.6$ & None \\
\hline $\mathrm{HX}+\mathrm{ECP}(10 \mu \mathrm{g})$ & $71.0 \pm 8.5$ & $180.4 \pm 23.2^{*}$ & $165.7 \pm 4.8$ & $217.9 \pm 13.5^{*}$ & $144.5 \pm 17.6$ & None \\
\hline $\mathrm{HX}+\mathrm{ECP}(50 \mu \mathrm{g})$ & $86.2 \pm 9.0$ & $158.2 \pm 21.8^{*}$ & $183.5 \pm 34.3$ & $212.1 \pm 15.5^{*}$ & $162.1 \pm 7.5$ & None \\
\hline $\mathrm{HX}+\mathrm{ECP}(250 \mu \mathrm{g})$ & $105.9 \pm 6.7$ & $227.1 \pm 7.1^{*}$ & $300.7 \pm 44.2^{*}$ & $307.4 \pm 9.3^{*}$ & $193.7 \pm 18.2$ & None \\
\hline $\mathrm{HX}+\mathrm{FSH}$ & $128.0 \pm 27.6^{*}$ & $152.3 \pm 8.7$ & $194.7 \pm 19.3$ & $115.8 \pm 21.1$ & $181.0 \pm 15.1$ & $110.5 \pm 9.1^{*}$ \\
\hline $\mathrm{HX}+\mathrm{FSH}+\mathrm{ECP}$ & $154.9 \pm 20.2^{*}$ & $237.7 \pm 9.2^{*}$ & $310.3 \pm 26.9^{*}$ & $460.1 \pm 31.3^{*}$ & $457.6 \pm 21.0^{*}$ & $145.9 \pm 14.9^{*}$ \\
\hline $\mathrm{HX}+\mathrm{FSH}+\mathrm{DES}$ & $195.0 \pm 29.3^{*}$ & $253.2 \pm 22.6^{*}$ & $261.5 \pm 27.8^{*}$ & $362.5 \pm 48.9^{*}$ & $301.4 \pm 24.2^{*}$ & $117.7 \pm 4.7^{*}$ \\
\hline $\mathrm{HX}+\mathrm{FSH}+\mathrm{DHT}$ & $111.6 \pm 11.5$ & $135.7 \pm 5.6$ & $154.8 \pm 4.2$ & $533.2 \pm 60.8^{*}$ & $402.2 \pm 18.1^{*}$ & $153.0 \pm 8.9^{*}$ \\
\hline $\mathrm{HX}+\mathrm{FSH}+\mathrm{T}$ & $74.6 \pm 14.3$ & $137.6 \pm 4.9$ & $160.6 \pm 20.2$ & $361.3 \pm 49.5^{*}$ & $460.2 \pm 23.7^{*}$ & $273.3 \pm 12.2^{*}$ \\
\hline
\end{tabular}

'Different daily doses of oestradiol cyclopentylpropionate (ECP) in peanut oil, as indicated in the table, were injected s.c. once a day for 4 days beginning on day 12 after hypophysectomy (HX). Combinations of FSH $\left(4 \mu \mathrm{g}\right.$ day $\left.{ }^{-1}\right)$ and $250 \mu \mathrm{g}$ day ${ }^{-1}$ of ECP, diethylstilboestrol (DES), dihydrotestosterone (DHT), or testosterone (T) were also given for 4 days and the animals were killed on day 16 after hypophysectomy.

${ }^{*} P<0.05$, comparing different treatment groups with the hypophysectomized control group within that developmental stage, $n=4$.
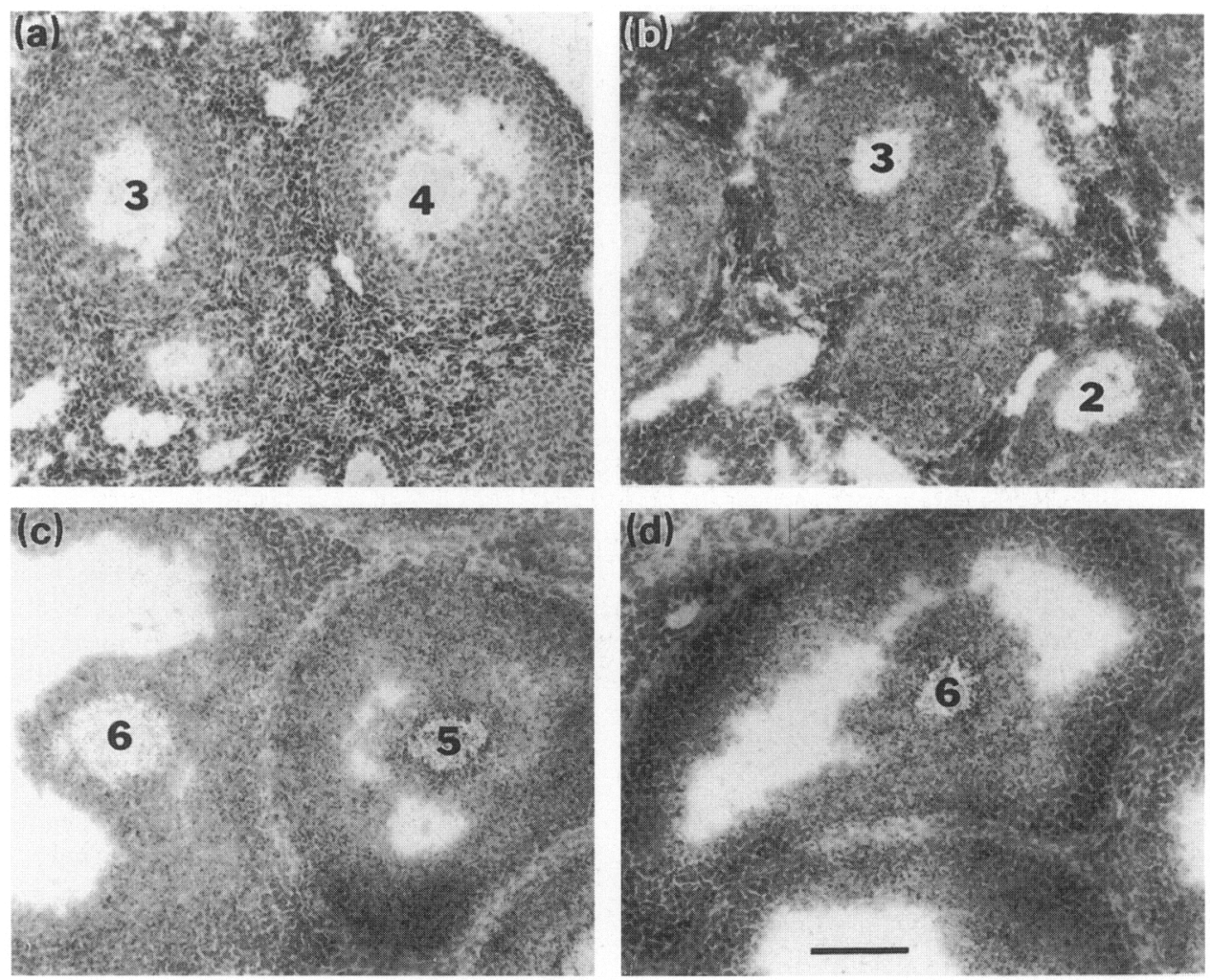

Fig. 4. Topical autoradiographs showing the effects of oestradiol replacement with or without FSH on intraovarian distribution of binding sites for ${ }^{125}[] \mathrm{FSH}$. The panels represent ovarian sections from hypophysectomized mice after treatment for 4 days. (a) hypophysectomized control: no significant binding grains in granulosa layers of follicles at stage 3 and 4; (b) $250 \mu \mathrm{g}_{\text {oestradiol cyclopentylpropionate day }}{ }^{-1}$, (c) $4 \mu \mathrm{g} \mathrm{FSH} \mathrm{day}{ }^{-1}$ or (d) oestradiol plus FSH. (b-d) show increasing binding density for FSH receptors in granulosa cells of preantral and antral follicles. Numbers in the figures represent the stage of follicles i.e. ' 3 ' is a stage 3 follicle. Scale bar $=70 \mu \mathrm{m}$ for all parts of this figure.

Unexpectedly, a dose of oestradiol as low as $10 \mu \mathrm{g} \mathrm{day}^{-1}$ for 4 days increased ovarian and uterine weights in hypophysectomized mice to the same degree as $250 \mu \mathrm{g}$ oestradiol, although serum oestradiol was only $240 \mathrm{pg} \mathrm{ml}^{-1}$. This correlates with the response of follicular development; i.e. 10 or $50 \mu \mathrm{g}$ oestradiol increased the number of follicles at all stages of 



Fig. 5. Typical autoradiographs of the effects of oestradiol replacement with or without FSH on intraovarian distribution of binding sites for $\left[{ }^{125} \mathrm{I}\right] \mathrm{hCG}$. The panels represent ovarian sections from hypophysectomized mice after injection of (a) $250 \mu \mathrm{g}$ oestradiol cyclopentylpropionate day ${ }^{-1}$ for 4 days: trace amounts of binding grains appear only in the interstitium; (b) $4 \mu \mathrm{g} \mathrm{FSH} \mathrm{day}{ }^{-1}$ for 4 days: binding activity appears only in mural granulosa layers of large antral follicles but not in thecal and interstitial tissues; (c) oestradiol plus FSH for 3 days; and (d) oestradiol plus FSH for 4 days. Treatment with oestradiol plus FSH induced hCG receptors in granulosa and thecal/interstitial regions. Numbers in the figures represent the stage of follicles i.e. ' 4 ' is a stage 4 follicle. Arrowheads point to thecal cells. Scale bar $=70 \mu \mathrm{m}$ for all parts of this figure.

development except for preovulatory follicles, but the rate of DNA synthesis increased only in follicles at stages 2 and 4 . This finding is consistent with the morphological changes of preantral follicles, in which there is a large oocyte surrounded by few layers of granulosa cells (not shown), comparable to the status in hypophysectomized control animals (Wang and Greenwald, 1993a). This implies that although the low doses of oestradiol (10 or $50 \mu \mathrm{g} \mathrm{day}^{-1}$ ) enhanced follicular development, the rate of proliferation of granulosa cells is slower than the growth of the oocyte; the transition time from one stage to the next may be longer, resulting in accumulation of more follicles at each stage. When oestradiol plus FSH or FSH plus $\mathrm{LH}$ are administered, follicular recruitment and proliferation are stimulated (Wang and Greenwald, 1993b).

A higher dose $(250 \mu \mathrm{g})$ of oestradiol stimulated the proliferation of granulosa cells, as shown by the increased rate of DNA synthesis and the large number of medium follicles with a large granulosa cell mass and small antral cavity; most of these follicles were healthy or at early stages of atresia. This result is comparable to a previous study of oestrogen administration to immature mice, although healthy and atretic follicles were not distinguished (Kim and Greenwald, 1987). In rats, high concentrations of oestrogens in follicular fluid also exert a direct antiatretic effect (Harman et al., 1975; Hsueh, 1986). However, the exact mechanism involved in stimulation of follicular growth and reduction of follicular atresia remains uncertain. This type of cell degeneration in follicular atresia is known as apoptosis (O'Shea et al., 1978). Experiments using RNA and protein synthesis inhibitors have shown suppression or induction of apoptosis, implying the presence of either intracellular repressors or inducers of apoptosis, which may be steroid or peptide hormones (Gerschenson and Rotello, 1992). For Downloaded from Bioscientifica.com at 04/26/2023 12:48:33PM 
example, removal of androgens results in apoptosis in the prostatic epithelium (Kyprianou et al., 1990); progesterone withdrawal elicits apoptosis in uterine epithelial cells (Rotello et al., 1991a) and transforming-growth factor- $\beta I$ induces apoptosis in primary cultures of uterine epithelial cells (Rotello et al., 1991b). Oestrogen may be one of the candidates regulating follicular atresia since oestradiol slows down the process of follicular atresia in hypophysectomized mice for the first 4 days of treatment; advanced atresia, however, has been observed when oestrogen treatment is continued for more than four days in immature hypophysectomized diethylstilboestrol-treated rats (Sadrkhanloo et al., 1987).

A combination of oestradiol and FSH results in superfollicular development in contrast to combinations of FSH plus LH; the latter treatment induces about the same number of preovulatory follicles as in normal cyclic mice (Halpin and Charlton, 1988; Wang and Greenwald, 1993b). The superfollicular development may be attributed to the high concentration of oestrogen, since the rate of DNA synthesis in follicles increases at all stages of development and none of the follicles becomes atretic. The mechanism for the synergistic effect of oestradiol with FSH has been investigated in rats and reviewed by Richards (1987) and Richards and Hedin (1988). Studies suggest that oestrogen increases FSH-induced adenylyl cyclase and cAMP formation (Richards et al., 1979; Knecht et al., 1984) and cAMP-dependent protein kinases, which in turn phosphorylate the oestradiol receptor in granulosa cells of large antral follicles in rats (Richards, 1975; Richards and Rolfes, 1980; Green et al., 1986). However, the existence of oestradiol receptors in mouse preantral follicles needs to be established to determine whether the effect of oestradiol on these follicles is directly mediated by receptors or indirectly mediated by growth factors, such as, transforming-growth factor- $\beta$ (Bendell and Dorrington, 1991).

Another mechanism by which oestrogen increases the response of granulosa cells to gonadotrophins is to induce FSH receptors on granulosa cells of follicles beyond stage 3 (late preantral follicles), as reported in hypogonadal mice (Charlton et al., 1982) and hypophysectomized immature rats, where it is cAMP-mediated (Goldenberg et al., 1972; Knecht et al., 1984). Treatment with oestradiol alone does not result in an increase in LH/hCG receptors on granulosa cells and thecal-interstitial tissues in rats (Rao et al., 1991) but, in hypogonadal mice (Charlton et al., 1982), oestrogen implanted for 5 days can induce formation of large antral follicles and hCG labelling on granulosa cells and interstitial and thecal cells. The different response to oestrogen between hypophysectomized and hypogonadal mice may be due to oestrogen acting directly in the pituitary to stimulate gonadotrophin secretion. In hypophysectomized mice, treatment with FSH alone induces hCG receptors on granulosa cells of large antral follicles, but not on the theca nor the interstitium (Wang and Greenwald, 1993b). Combined treatment with oestradiol and FSH induces hCG receptors on granulosa and thecal-interstitial regions. hCG receptors are observed even on stage 4 follicles (early antral stage); this is not the case in normal, cyclic mice (Wang and Greenwald, 1993a). Thus, oestradiol acts synergistically with FSH to enhance the differentiation of granulosa cells to express and synthesize LH/hCG receptors at an earlier stage than normal (Kessel et al., 1985; Segaloff et al., 1990).
As reported previously, treatment with FSH alone did not induce oestradiol production (Schoot et al., 1992; Wang and Greenwald, 1993b). This may be attributable not to lower aromatase activity (Mannaerts et al., 1991) but to reduced amounts of precursors of oestradiol, progesterone and androstenedione as a consequence of undeveloped or undifferentiated thecal cells in the absence of LH stimulation. Oestradiol combined with FSH increases progesterone, androstenedione and oestradiol in serum and in the in vitro medium. This finding implies that oestrogen and FSH are both required for the entire steroid pathway in follicles, as in rats (Fitzpatrick and Richards, 1991). Oestradiol cyclopentylpropionate dissociates in vivo into oestradiol (Greenwald, 1975), which was measurable by radioimmunoassay. It is possible that the accumulation of oestradiol in medium represents storage in follicles of oestradiol derived from injected oestradiol cyclopentylpropionate. However, diethylstilboestrol combined with FSH also showed the same effects as oestradiol cyclopentylpropionate on the in vitro accumulation of progesterone, androstenedione and oestradiol. Since diethylstilboestrol does not crossreact with the oestradiol radioimmunoassay, the possibility of contamination can be ruled out.

The present study also demonstrates that concurrent treatment with FSH and androgens, dihydrotestosterone (nonaromatizable) and testosterone stimulates only antral follicle growth (but not preantral follicles), prevents atresia and stimulates progesterone, androstenedione and oestradiol production. These results are consistent with the conclusion that androgens enhance FSH-induced aromatase activity and gene expression in cultured rat granulosa cells (Daniel and Armstrong, 1980; Fitzpatrick and Richards, 1991), but is not consistent with the conclusion that dihydrotestosterone reduces ovulation rate by decreasing the number of granulosa cells of follicles and by altering the ability of the cells in immature PMSG-treated rats to synthesize oestrogen (Conway et al, 1990). These studies suggest that the ovarian actions of androgens are diverse. Generally, in the absence of FSH, androgens exert mainly negative effects (Conway et al., 1990), whereas in the presence of $\mathrm{FSH}$, androgens augment FSH stimulation of progesterone and oestradiol biosynthesis by enhancing aromatase activity in rat granulosa cells (Daniel and Armstrong, 1980; Conway and Mills, 1991). Thus, LH regulation of thecal cell production of androgens in rats and mice plays a key role in determining ultimately which follicles continue to respond to $\mathrm{FSH}$ and undergo differentiation.

It is not surprising that exogenous testosterone enhances the production of oestradiol because it can be converted to oestradiol by aromatase, induced in granulosa cells by FSH (Mannaerts et al., 1991). Dihydrotestosterone cannot be converted to oestrogens. However, it directly stimulates the gene expression of aromatase as effectively as oestradiol and testosterone (Fitzpatrick and Richards, 1991). This finding suggests that during follicular development, theca-derived androgens enhance the actions of FSH and serve as stimulators and substrates for aromatase. The induction of oestradiol production by androgens also explains why superfollicular development occurs without any signs of atresia when FSH is combined not only with $\mathrm{LH}$ and oestrogens but also with androgens. In an in vitro culture system, testosterone acting synergistically with FSH was more effective in stimulating oestradiol production 
than was dihydrotestosterone (Daniel and Armstrong, 1980). However, the ovarian actions of testosterone in the present study are not as effective as oestradiol cyclopentylpropionate and dihydrotestosterone in stimulating production of progesterone, androstenedione and oestradiol and preventing atresia; presumably because testosterone administered in vivo can be converted to a variety of metabolites in extra-ovarian tissues. In addition, dihydrotestosterone has a higher affinity for the androgen receptor than does testosterone in the rat prostate (Lamb et al., 1992); this provides another explanation for the observation that dihydrotestosterone is more effective than testosterone in stimulating folliculogenesis and steroidogenesis.

The authors appreciate the generous gifts of purified hormones from the National Hormone and Pituitary Program, the National Institute of Diabetes and Digestive and Kidney Diseases, University of Maryland School of Medicine, Baltimore, MD and Pituitary Hormones and Antisera Center, Harbor-UCLA Medical Center, Torrance, CA. We are also grateful to $D$. Limback for her excellent assistance. This work is supported by NIH Grant HD-00596(30) and HD-02528.

\section{References}

Barkley MS, Lasley BL, Thompson MA and Shackleton CHL (1985) Equol: a contributor to enigmatic immunoassay measurements of estrogen Steroids $\mathbf{4 6}$ $587-608$

Bendell JJ and Dorrington J (199I) Estradiol-17 $\beta$ stimulates DNA synthesis in rat granulosa cells: Action mediated by transforming growth factor- $\beta$ Endocrinology 128 2663-2665

Catt KJ, Keteislegers J and Dufau ML (1976) Receptors for gonadotropic hormones. In Methods in Receptor Research, pp 175-250 Ed. M. Blecher. Marcel Dekker Inc., New York

Charlton HM, Parry D, Halpin DMG and Webb R (1982) Distribution of ${ }^{125}$ Ilabelled follicle-stimulating hormone and human chorionic gonadotrophin in the gonads of hypogonadal ( $\mathrm{kpg}$ ) mice Journal of Endocrinology $93 \quad 247-252$

Conway BA and Mills TM (1991) In vitro effects of dihydrotestosterone on granulosa cell production of estrogen and progesterone Steroids 56 258-262

Conway BA, Mahesh VB and Mills TM (1990) Effect of dihydrotestosterone on the growth and function of ovarian follicles in intact immature female rats primed with PMSG Journal of Reproduction and Fertility 90 267-277

Daniel SAJ and Armstrong DT (1980) Enhancement of follicle-stimulating hormone-induced aromatase activity by androgens in cultured rat granulosa cells Endocrinology 107 1027-1033

Fitzpatrick SL and Richards JS (1991) Regulation of cytochrome P450 aromatase messenger ribonucleic acid and activity of steroids and gonadotropins in rat granulosa cells Endocrinology 129 1452-1462

Gerschenson LE and Rotello RJ (1992) Apoptosis: a different type of cell death FASEB Joumal 6 2450-2455

Goff AK and Henderson KM (1979) Changes in follicular fluid and serum concentrations of steroids in PMS treated immature rats following $\mathrm{LH}$ administration Biology of Reproduction 20 1153-1157

Goldenberg RL, Vaitukaitis JL and Ross GT (1972) Estrogen and follicle stimulating hormone interactions on follicle growth in rats Endocrinology 90 1492-1498

Green A, Walter P, Kumar R, Kurst A, Bornert JM, Argos P and Chambon P (1986) Human estrogen receptor CDNA: Sequence expression and homology to $v$-erb-a Nature 320 134-139

Greenwald GS (1975) Proestrous hormone surges dissociated from ovulation in the estrogen-treated hamster Endocrinology 97 878-890

Halling A and Forsberg JG (1990) Steroid synthesis in ovarian homogenates from immature mice treated with diethylstilboestrol in neonatal life Journal of Reproduction and Fertility 88 399-404

Halpin DMG and Charlton HM (1988) Effects of short-term injection of gonadotrophins on ovarian follicle development in hypogonadal (hpg) mice Joumal of Reproduction and Fertility 82 393-400

Harman M, Louvet JP and Ross GT (1975) Interaction of estrogen and gonadotropins on follicular atresia Endocrinology 96 1145-1152
Hsueh AJ (1986) Paracrine mechanisms involved in granulosa cell differentiation Joumal of Clinical Endocrinology and Metabolism 15 117-134

Hutz RJ (1989) Disparate effects of estrogens on in vitro steroidogenesis by mammalian and avian granulosa cells Biology of Reproduction 40 709-713

Kent J (1973) Some effects of steroids on the immature mouse ovary in vitro Journal of Reproduction and Fertility 4 297-303

Kessel B, Liu YX, Jia XC and Hsueh AJW (1985) Autocrine role of estrogens in the augmentation of luteinizing hormone receptor formation in cultured rat granulosa cells Biology of Reproduction 32 1038-1050

Kim I and Greenwald GS (1986) Occupied and unoccupied FSH receptors in follicles of cyclic, hypophysectomized or hypophysectomized gonadotropintreated hamster Molecular and Cellular Endocrinology 44 141 -145

Kim I and Greenwald GS (1987) Effect of estrogens on follicular development and ovarian and uterine estrogen receptors in the immature rabbit, guinea pig and mouse Endocrinologia Japonica 34 871-878

Knecht M, Darbon JM, Ranta T, Baukal AJ and Catt KJ (1984) Estrogens enhance the adenosine $3^{\prime}, 5^{\prime}$-monophosphate-mediated induction of follicle-stimulating hormone and luteinizing hormone receptors in rat granulosa cells Endocrinology $11541-9$

Kyprianou N, English HF and Isaacs JT (1990) Programmed cell death during regression of $\mathrm{PC}-82$ human prostate cancer following androgen ablation Cancer Research 50 3748-3753

Lamb JC, English H, Levandoski PL, Rhodes GR, Johnson RK and Isaacs JT (1992) Prostatic involution in rats induced by a novel 5 -alpha-reductase inhibitor, SK-and-F-105657: role for testosterone in the androgenic response Endocrinology $130685-694$

Mannaerts B, Deleeuw R, Geelen J, Vanravestein A, Vanwezenbeek P, Schuurs A and Kloosterboer $\mathrm{H}$ (1991) Comparative in vitro and in vivo studies on the biological characteristics of recombinant human follicle-stimulating hormone Endocrinology $1292623-2630$

O'Shea JD, Hay MF and Cran DG (1978) Ultrastructural changes in the theca interna during follicular atresia in sheep Journal of Reproduction and Fertility $\mathbf{5 4}$ 183-187

Oxberry BA and Greenwald GS (1982) An autoradiographic study of the binding of ${ }^{125}$ I-labelled follicle-stimulating hormone, human chorionic gonadotropin and prolactin to the hamster ovary throughout the estrous cycle Biology of Reproduction 27 505-516

Payne RW and Hellbaum AA (1955) The effects of estrogens on the ovary of the hypophysectomized rat Endocrinology 57 193-199

Pencharz RI (1940) Effects of estrogens and androgens alone and in combination with chorionic gonadotropin on the ovary of the hypophysectomized rat Science 91 553-554

Rao IM, Mills TM, Anderson E and Mahesh VB (1991) Heterogeneity in granulosa cells of developing rat follicles Anatomical Record 229 177-185

Richards IS (1975) Estradiol receptor content in rat granulosa cells during follicular development: modification by estradiol and gonadotropins Endocrinology 97 1174-1184

Richards JS (1980) Maturation of ovarian follicles: actions and interactions of pituitary and ovarian hormones on follicular cell development Physiological Reviews 60 51-89

Richards JS (1987) Ovarian follicular development: from physiology to molecular biology Recent Progress in Hormone Research 43 231-276

Richards JS and Hedin L (1988) Molecular aspects of hormone action in ovarian follicular development, ovulation and luteinization Annual Review of Physiology 50 441-463

Richards JS and Rolfes AI (1980) Hormonal regulation of cAMP binding to specific receptor proteins in rat ovarian follicles. Characterization by photoaffinity labelling Journal of Biological Chemistry 255 5491-5498

Richards JS, Jonassen JA, Rolfes AI, Kersey K and Reichert LE, Jr (1979) Adenosine $3^{\prime}, 5^{\prime}$-monophosphate, luteinizing hormone receptor, and progesterone during granulosa cell differentiation: effects of estradiol and follicle-stimulating hormone Endocrinology 104 765-773

Rotello RJ, Lieberman RC, Lepoff RB and Gerschenson LE (1991a) Characterization of uterine epithelium apoptotic cell death kinetics and regulation by progesterone and RU486 American Journal of Pathology 140 449-456

Rotello RJ, Lieberman RC, Purchio AF and Gerschenson LE (1991b) Coordinated regulation of apoptosis and cell proliferation by TGF- $\beta 1$ in cultured cells Proceedings of the National Academy of Sciences USA 88 3412-3415

Roy SK and Greenwald GS (1986) Quantitative analysis of in vitro incorporation of $\left[{ }^{3} \mathrm{H}\right]$ thymidine into hamster follicles during the oestrous cycle Journal of Reproduction and Fertility 77 143-152

Roy SK, Wang SC and Greenwald GS (1987) Radioreceptor and autoradiographic analysis of FSH, hCG and prolactin binding sites in primary to antral Downloaded from Bioscientifica.com at 04/26/2023 12:48:33PM 
hamster follicles during the periovulatory period Journal of Reproduction and Fertility 79 307-313

Sadrkhanloo R, Hofeditz C and Erickson GF (1987) Evidence for widespread atresia in the hypophysectomized estrogen-treated rat Endocrinology 120 146-155

Schoot DC, Bennink HJTC, Mannaerts BMJL, Lamberts SWJ, Bouchard P and Fauser BCJM (1992) Human recombinant follicle-stimulating hormone induces growth of preovulatory follicles without concomitant increase in androgen and estrogen biosynthesis in a woman with isolated gonadotropin deficiency Journal of Clinical Endocrinology and Metabolism 74 1471-1473

Segaloff DL, Wang H and Richards IS (1990) Hormonal regulation of luteinizing hormone/chorionic gonadotropin receptor mRNA in rat ovarian cells during follicular development and luteinization Molecular Endocrinology 4 1856-1865

Smith DM and Tenney DY (1979) Effect of hypophysectomy on mouse oocyte maturation in vitro Journal of Reproduction and Fertility 55 415-422
Terranova PF and Greenwald GS (1978) Steroid and gonadotropin levels during the luteal-follicular shift of the cyclic hamster Biology of Reproduction 18 170-175

Tonetta SA and diZerega GS (1989) Intragonadal regulation of follicular maturation Endocrine Reviews 10 205-229

Wang XN and Greenwald, GS (1993a) Hypophysectomy of the cyclic mouse: I. Effects on folliculogenesis, oocyte growth and FSH- and hCG-receptors Biology of Reproduction 48 585-594

Wang XN and Greenwald GS (1993b) Hypophysectomy of the cyclic mouse: II. Effects of FSH and LH on folliculogenesis, FSH- and hCG-receptors and steroidogenesis Biology of Reproduction 48 595-605

Wang XN, Roy SK and Greenwald GS (1991) In vitro DNA synthesis by isolated preantral to preovulatory follicles from the cyclic mouse Biology of Reproduction $44857-863$

Williams PC (1940) Effect of stilboestrol on the ovaries of the hypophysectomized rat Nature 145 388-389 